\title{
Refleksi Hukum Lex Talionis dalam Keluaran 21:22-25 Demi Terwujudnya Keadilan Hukum di Indonesia
}

\author{
Andri Arbet Laik', Grant Nixon², Martina Novalina ${ }^{3}$ \\ ${ }^{1,2,3}$ Sekolah Tinggi Teologi Ekumene, Jakarta \\ Correspondence: andriarbetlaik@sttekumene.ac.id
}

\begin{abstract}
Lex Talionis law is generally understood as a form of law that demands maximum retaliation. This law is then used as a reference in order to legalize all forms of revenge. This study aims to look at the Lex Talionis law from the perspective of the book of Exodus 21:22-25. The method used in this research uses literature review, which results in an understanding that the Lex Talionis law has a practical implication, especially regarding the value of legal justice that can be submitted to perpetrators of injustice through the courts so that justice will be realized as expected. The main element in the Lex Talionis law does not refer to maximum revenge efforts but instead refers to aspects of God's justice in responding to every legal case that applies to mankind. Thus the Lex Talionis law is no longer seen as a law of revenge but becomes a law of justice that allows it to be implemented in today's society.
\end{abstract}

Keywords: Exodus 21; God's justice; law; Lex Talionis

\begin{abstract}
Abstrak: Hukum Lex Talionis umumnya dipahami sebagai sebuah bentuk hukum yang menuntut tindakan balas dendam secara maksimal. Melalui hukum ini kemudian dijadikan rujukan agar bisa melegalkan semua bentuk pembalasan dendam. Kajian ini hendak melihat hukum Lex Talionis dari sudut pandang kitab Keluaran 21:22-25. Metode yang digunakan dalam penelitian ini menggunakan kajian pustaka, yang menghasilkan sebuah pemahaman bahwa hukum Lex Talionis memiliki sebuah implikasi praktis, khususnya perihal nilai keadilan hukum yang bisa diajukan kepada pelaku ketidakadilan melalui pengadilan, sehingga akan terwujud keadilan seperti yang diharapkan. Unsur utama dalam hukum Lex Talionis justru tidak menunjuk pada upaya pembalasan dendam secara maksimal, tetapi justru menunjuk pada aspek keadilan Allah dalam menanggapi setiap kasus hukum yang berlaku atas umat manusia. Dengan demikian hukum Lex Talionis bukan dipandang lagi sebagai hukum pembalasan dendam, melainkan menjadi sebuah hukum keadilan yang memungkinkan untuk dapat diimplementasikan dalam kehidupan masyarakat pada masa kini.
\end{abstract}

Kata kunci: hukum; keadilan Allah; Keluaran 21; Lex Talionis

\section{Pendahuluan}

Para ahli menganggap bahwa hukum Lex Talionis adalah hukum yang yang memiliki kaitan erat dengan hukum Hammurabi yang dalam sejarah Timur-Tengah kuno. Menurut sejarah hukum Hammurabi diciptakan bagi bangsa Babilonia Kuno demi menciptakan suatu ketertiban dan keadilan bagi rakyat agar mereka bisa mengalami damai sejahtera. ${ }^{1}$ Namun sesungguhnya hukum Hammurabi sangat berbeda dengan hukum milik bangsa Israel, sebab

\footnotetext{
${ }^{1}$ Moriska Simamora, Lex Talionis (Menurut Keluaran 21:22-25) (Yogyakarta: Diandra Kreatif (Kelompok Penerbit Diandra), 2018).
} 
otoritas atas hukum Israel bukan terletak pada Musa melainkan pada Allah yang diberikan melalui Musa. Hukum milik bangsa Israel bukan hukum yang mesti ditegakan oleh pengadilan negeri. Sebab hukum Israel adalah hukum yang diberikan Allah yang berupa petunjuk mengenai cara hidup bersosial yang benar serta memuat hukum etika dan moral yang dalam pelaksanaanya langsung diawasi oleh Allah. Terdapat salah satu perbedaan mencolok yaitu bahwa prinsip Lex Talionis dalam hukum Hammurabi hanya berlaku bagi orang yang sesama kelas atau satu kasta, tetapi prinsip Lex Talionis dalam hukum Israel berlaku bagi segenap bangsa Israel tanpa memandang kelas atau status sosial. ${ }^{2}$ Hukum Lex Talionis dalam Hammurabi mengatur hubungan antara rakyat dan raja mereka, tetapi Lex Talionis dalam hukum Israel mengatur antara relasi manusia dengan Allah.

Dengan mengacu pada fakta tentang hukum Lex Talionis ini, maka penulis akan melakukan kajian terhadap teks Keluaran 21:22-25 untuk mengaitkannya dengan realita hukum di Indonesia untuk mendapat suatu pandangan baru tentang bagaimana seharusnya suatu proses hukum yang baik dilaksanakan demi keadilan. Sejak bangsa Indonesia merdeka, masih banyak problematika dan permasalahan yang tidak kunjung selesai, seperti kekerasan dan ketidakadilan hukum yang masih mewarnai perjalanan bangsa ini. khususnya dalam konteks hak asasi manusia, kasus diskriminasi, intoleransi, maupun konflik agraria. Menurut data dari lembaga Komisi Nasional Hak Asasi Manusia per tanggal 02 September 2020, terdapat 2.757 laporan yang diterima soal masalah tersebut. Tiga daerah dengan pengaduan terbanyak adalah, DKI Jakarta (414 laporan), Sumatera Utara (248 laporan), Jawa Timur (248 laporan). Dan pihak yang paling banyak dilaporkan adalah Polri (744 laporan), korporasi (483 laporan), dan pemda terdapat 315 laporan. $^{3}$ Menurut Ashinta, terdapat krisis kepercayaan akan keadilan hukum menjadi semakin merajalela, karena kasus-kasus hukum yang dialami oleh rakyat kecil cenderung mendapat tekanan hukum yang sangat kuat, tetapi sebaliknya hukum lemah untuk kasus-kasus besar yang merugikan negara. ${ }^{4}$ Bahkan Jaksa Agung Republik Indonesia ST Burhanudin mengakui penegakan hukum di Indonesia belum memenuhi rasa keadilan, ia mencontohkan kasus yang ada di Sumatera Utara, yakni seorang kakek berusia 68 tahun divonis 2 bulan karena dituduh mencuri getah pohon karet seberat 1,9 Kilogram seharga Rp 17.00. ST Burhanudin mengatakan bahwa, penegakan hukum hanya berdasarkan pada yuridis formal, sehingga penegakan hukum mesti ditegakan untuk dapat memberi rasa aman dan adil kepada masyarakat ${ }^{5}$.

Untuk itu dengan membahas hukum Lex Talionis dalam teks bertujuan untuk menemukan makna Lex Talionis dalam hukum Israel guna ditemukan makna orisinalnya untuk diterapkan demi keadilan hukum. Dalam kajiannya VanDrunen mengatakan bahwa Lex Talionis tetap relevan secara hukum dan teologis dalam menyatukan dua gagasan yang sangat

${ }^{2}$ Firman Panjaitan and Marthin Lumingkewas, "KEADILAN DALAM HUKUM LEX TALIONIS: TAFSIR TERHADAP KELUARAN 21:22-25," Pengarah: Jurnal Teologi Kristen 1 (July 31, 2019): $73-84$.

${ }^{3}$ Komnas HAM, "75 Tahun Indonesia Merdeka, Sebuah Harapan Bagi Penghormatan HAM Komnas HAM," last modified 2020, accessed May 30, 2021, https://www.komnasham.go.id/index.php/news/2020/9/2/1545/75-tahun-indonesia-merdeka-sebuahharapan-bagi-penghormatan-ham.html.

${ }^{4}$ Ashinta Sekar Bidari, "Ketidakadilan Hukum Bagi Kaum Sandal Jepit" (Universitas Surakarta, n.d.).

${ }^{5}$ Deti Mega Purnamasari, "Jaksa Agung Akui Penegakkan Hukum Di Indonesia Belum Penuhi Rasa Keadilan," last modified 2020, accessed June 2, 2021, https://nasional.kompas.com/read/2020/02/17/12002291/jaksa-agung-akui-penegakkan-hukum-diindonesia-belum-penuhi-rasa-keadilan. 
penting: Pertama, bahwa hukum kodrat adalah standar untuk hukum perdata, dan Lex Talionis sebagai ekspresi keadilan yang ketat dan proporsional yang secara alami dikenal dan secara Alkitabiah. ${ }^{6}$ Lenta, mengungkapkan bahwa Lex Talionis tidak boleh dijadikan alasan untuk menjatuhkan hukuman mati sebagai pelaku kejahatan, sebab itu tidak akan memadamkan penghinaan terhadap kemanusiaan, untuk itu sebaiknya masyarakat tempat pelaku kejahatan menjatuhkan sanksi berupa pengusiran dan penjara seumur hidup sebagai pengganti hukuman mati. ${ }^{7}$ Berdasarkan latar belakang permasalahan yang ada, maka penulis bermaksud mengkaji teks dalam kitab Keluaran 21:22-25 berdasarkan kaidah-kaidah hermeneutika untuk menemukan implikasi yang kontekstual bagi gereja agar bisa diterapkan di tengah berbagai permasalahan ketidakadilan hukum di Indonesia. Teks dalam bagian Keluaran 21:22-25 membahas tentang Hukum Lex Talionis. Hukum Lex Talionis memuat suatu jenis pernyataan hukum yang berisi tentang berbagai panduan mengenai berbagai kejahatan khusus yang patut menerima hukuman mati seperti yang ada dalam Keluaran 21:22-25 yang juga terdapat dalam tradisi hukum Timur Dekat kuno, yang meliputi hukum perdata seperti hukum perkawinan, hukum warisan, utang, pungutan pajak, dan upah. Serta hukum seremonial yang terdiri dari hukum pembunuhan, hukum perzinahan, pencurian, pemerkosaan, serta penyimpangan seksual ${ }^{8}$.

Berdasarkan latar belakang permasalahan yang ada maka penulis melihat bahwa gerejagereja di Indonesia cenderung masih lemah dalam mengatasi masalah ketidakadilan. Gerejagereja di Indonesia masih kurang dalam memberi kontribusi pendampingan hukum, sehingga banyak tercipta kasus ketidakadilan. Gereja cenderung berdiam di saat terdapat ribuan kasus ketidakadilan, padahal sesungguhnya dalam dalam situasi demikian gereja patut menjadi agen untuk memperjuangkan keadilan bagi setiap orang di lingkungan gereja atau paling tidak terhadap warga gereja sendiri. Oleh karenanya gereja harus mampu mengajukan keberatankeberatan atas persoalan keadilan yang tidak seimbang supaya terdapat pembelaan dihadapan hukum, sebab dihadapan hukum segala sesuatu seharus nya sejajar dan sederajat, sebab dalam penegakan hukum, tidak boleh ada diskriminasi.

\section{Metode Penelitian}

Teks Keluaran 21:22-25 akan dibedah dengan menggunakan metode penafsiran hukum, penulis akan menyelidiki hukum-hukum yang mengelilinginya untuk menemukan petunjuk penafsiran yang tepat, kemudian penafsir akan berusaha memahami latar belakang historis di balik hukum tersebut untuk menemukan makna orisinalnya untuk diambil implikasinya yang kontekstual. ${ }^{9}$ Pada langkah pertama, penulis akan membahas fakta hukum lex talionis dan mengaitkannya dengan fakta hukum di Indonesia di bagian pendahuluan. Lalu pada bagian pembahasan, penulis akan membahas sejarah lex talionis dan latar belakang kitab Keluaran demi menemukan latar belakang hukum dalam teks Keluaran 21:22-25. Kemudian teks akan dianalisis untuk ditemukan makna orisinalnya. Pada akhirnya, di bagian kesimpulan, akan dikaitkan hasil analisis teks dan relevansinya bagi keadilan hukum di Indonesia.

\footnotetext{
${ }^{6}$ David VanDrunen, "Natural Law, the Lex Talionis, and the Power of the Sword," Liberty University Law Review 2, no. 3 (March 2008).

7 Patrick Lenta, "The Lex Talionis, the Purgative Rationale, and the Death Penalty," Criminal Justice Ethics 34 (2015): 42-63.

${ }^{8}$ Panjaitan and Lumingkewas, "Keadilan Dalam Hukum Lex Talionis: Tafsir Terhadap Keluaran 21:22-25." 2016).

${ }^{9}$ William W. Klein, Introduction to Biblical Interpretation 2: Pengantar Tafsiran Alkitab (Malang,
} 


\section{Pembahasan}

\section{Selayang pandang Hukum Lex Talionis}

Umumnya hukum lex talionis dipahami sebagai sebuah bentuk hukum yang menekankan pembalasan dendam, yang dalam pengertian pembalasan secara maksimal. ${ }^{10}$ Dan di bagian lain hukum ini dipandang sebagai hukum yang menyatakan balasan bagi pihak yang bersalah dan di tuntut untuk menderita secara setimpal. ${ }^{11}$ Dengan pengertian ini maka penulis dapat mendefinisikan bahwa hukum lex talionis adalah hukum yang menuntut sebuah perbuatan timbal balik bagi pihak yang bersalah, yang karena perbuatannya itu mendatangkan kerugian terhadap orang lain. Mengenai hal ini maka Th. C. Vriezen menyatakan bahwa hukuman dalam Keluaran 21:22-25 diberikan dengan tujuan untuk mencegah pelanggaranpelanggaran ekstrim, yaitu bahwa jika seseorang melakukan suatu pelanggaran yang bisa mendatangkan sebuah luka bagi orang lain, maka orang tersebut layak untuk menerima sebuah sanksi, dan orang yang melakukan pelanggaran tersebut harus menjalani hukuman tersebut sebagai sebuah bentuk tanggung jawab dari penerima hukuman tersebut sebagai sebuah bentuk tanggung jawab. ${ }^{12}$ Dari penjelasan ini maka dapat diketahui bahwa, hukum lex talionis diberlakukan untuk dapat membela hak-hak asasi dari umat Israel yang bertujuan untuk melindungi atau memberikan keadilan bagi umat Israel.

Untuk dapat diketahui bahwa di Mesopotamia, tindakan melukai dan merugikan seorang bangsawan biasanya dikenai hukuman yang lebih berat, dari pada melukai seseorang dari kalangan bawah. Tetapi di Israel sebalik nya terdapat kesetaraan di depan hukum yang baik bagi semua orang dari seluruh lapisan sosial, termasuk orang asing dan para pendatang ${ }^{13}$. Dalam hal ini hukuman diberikan untuk menunjukkan manusia sebagai seorang yang bertanggung jawab yang memiliki rasio dengan kesadaran melakukan pelanggaran dan harus tetap menjalani hukuman tersebut. Hukum dibangsa Israel termasuk hukum Lex Talionis memiliki ikatan pada perjanjian antara Allah dan bangsa Israel. Hukuman mati adalah bagian yang terdapat dalam perjanjian Allah dengan umat Israel. ${ }^{14}$ Oleh karenanya perjanjian itu harus dilindungi baik oleh Allah sebagai pihak pemberi maupun Israel sebagai penerima. Hukum ini berlaku bagi semua umat Israel dan kalau terdapat pelanggaran di dalam nya maka hukum ini berlaku untuk memberikan sanksi dan pihak yang menerima hukum tersebut harus menjalani hukum tersebut termasuk hukuman mati.

Umumnya terdapat dua jenis hukum dalam budaya Timur Dekat Kuno yaitu, hukum absolut yang dikenal dengan hukum apodiktik dan hukum kasus yang biasa dikenal dengan hukum kasuistik. Dekalog atau sepuluh hukum merupakan hukum apodiktik karena bersifat absolut atau mutlak yang harus ditaati. Sedangkan hukum kasuistik terdapat di dalam banyak ketetapan dan peraturan mengenai hal yang kudus dan tidak kudus untuk para imam dan orang awam (Im. 19) dan kode Taurat (UI.12-26). Hukum Lex Talionis mengandung hukum apodiktik dan juga hukum yang berlaku sebagai hukum pembalasan sekaligus wujud perlindungan bagi hukum itu sendiri dan bagi umat Israel yang menjalani hukum tersebut.

${ }^{10}$ Robert M. Peterson, Tafsiran Alkitab: Kitab Keluaran (Jakarta: BPK Gunung Mulia, 2006).

${ }^{11}$ Roy Zuck, Biblical Theology of The Old Testament (Malang: Penerbit Gandum Mas, 2005).

${ }^{12}$ Th. C. Vriezen., Agama Israel Kuno (Jakarta: BPK Gunung Mulia, 2015). Mulia, 1995).

${ }^{13}$ Christopher Wright, Hidup Sebagai Umat Allah-Etika Perjanjian Lama (Jakarta: BPK Gunung

${ }^{14}$ Gary Edward Schnittjer, The Torah Story (Malang: Penerbit Gandum Mas, 2015). 


\section{Latar Belakang Kitab Keluaran}

Walaupun keluarnya bangsa Israel dari Mesir adalah masalah utama yang dibahas dalam kitab Keluaran, namun sesungguhnya penulisan kitab ini memiliki tujuan yang lebih agung dimulai dari persiapan keberangkatan sampai selesai nya perjalanan pelarian tersebut, yang lebih memuat hal-hal teokratis daripada historis. Yaitu bahwa tujuan utama dari penulisan kitab adalah hendak menjelaskan tentang pemenuhan janji Allah kepada leluhur Israel, yaitu: Abraham, Ishak, dan Yakub, yang dimulai dari perkembangan keturunan yang cepat menjadi suatu bangsa yang besar. ${ }^{15}$ Kitab keluaran dapat dengan mudah dibagi kedalam tiga bagian kumpulan cerita yang berdasarkan pada urutan lokasi geografis bagi bangsa Israel sewaktu mereka mengadakan perjalanan dari Mesir ke Sinai:

1. Israel di Mesir (1:1-13:16)

2. Perjalanan Israel di padang gurun (13:17-18:27)

3. Israel di Sinai (19:1-40:38)

Bagian pertama 1 menceritakan mengenai hukuman Allah terhadap Mesir dan melepaskan bangsa Israel dari perbudakan. Bagian 2 kitab ini menjelaskan tentang bagaimana pimpinan dan karya Allah yang mengubah sebuah bangsa bekas budak menjadi umat kesayanganNya, melalui persetujuan perjanjian (covenant) di Sinai (19:1-6). Bagian 3 memberikan sebuah rincian tentang kemah suci Allah dan segala peralatan-peralatannya. Kehadiran Allah ditengah bangsa Israel telah ditetapkan melalui kemah pertemuan ini. ${ }^{16}$

Tema utama dalam kitab ini adalah Kesepuluh hukum yang juga dikenal dengan Dekalog yang tertulis dalam Keluaran 20:1-17. Kesepuluh hukum diberikan kepada umat Israel, tanpa campur tangan Musa, tetapi Allah sendiri lah yang memberikan hukum ini dengan menuliskan pada dua loh batu. Suatu hal yang menarik yaitu: Bahwa setelah pemberian hukum itu, Allah menyatakan diri-Nya kepada umat dari langit dan bukan dari Sinai (Kel. 20:22), hal ini menunjukan bahwa Allah yang memberikan hukum itu adalah Allah yang memiliki sifat sempurna dan kekal. Hanya dua hukum yang diberikan Allah dalam bentuk perintah positif yaitu, Ingat lah dan kuduskanlah hari sabat..." serta hormatilah ayah dan ibumu..." (Kel. 20:8-12). Selain itu delapan dari sepuluh hukum yang lain memiliki suatu larangan yang pasti (menggunakan tata bahasa janganlah kamu..."). ${ }^{17}$ Konstruksi tata bahasa yang khusus pada delapan hukum ini memiliki otoritas yang mengikat semua generasi yang ada pada waktu di padang gurun sampai kepada seluruh generasi yang akan datang dari Umat Israel.

Nada keras dalam sepuluh hukum ini menandai sifat mutlak dan permanen dari hukum ilahi tersebut. Empat hukum pertama memberikan pijakan atau penuntun tentang bagaimana umat memiliki sebuah relasi yang benar dengan Allah, dan enam hukum berikutnya menggambarkan tentang bagaimana umat harus memiliki sebuah relasi yang benar dengan sesamanya. Ketaatan umat Israel kepada perjanjian hukum ini sebenarnya bukan hanya sebagai bentuk ucapan terima kasih kepada Allah, tetapi tujuan perjanjian ini adalah untuk menciptakan sebuah hubungan yang baru antara Allah dan umat. Kesepuluh hukum ini menyatakan sifat moral yang sempurna dan kekal dari Allah, yang merupakan prinsip-prinsip dasar yang mengatur kehidupan umat Israel.

${ }^{15}$ C.F. Keil and F. Delitzsch, Keil and Delitzsch Commentary On The Old Testament (Edinburgh: T.\&T. Clark, 1866).

${ }^{16}$ Andrew E. Hill and John H. Walton, Survey Perjanjian Lama (Malang: Penerbit Gandum Mas, 2018).

$17 \mathrm{lbid}$. 


\section{Analisis terhadap Keluaran 21:22-25}

Untuk memahami akan makna hukum Lex Talionis dalam Keluaran 21:22-25 maka terlebih dahulu penulis menampilkan terlebih dahulu terjemahan teks sebagai berikut:

Terjemahan Baru:

Keluaran 21:22 Apabila ada orang berkelahi dan seorang dari mereka tertumbuk kepada seorang perempuan yang sedang mengandung, sehingga keguguran kandungan, tetapi tidak mendapat kecelakaan yang membawa maut, maka pastilah ia didenda sebanyak yang dikenakan oleh suami perempuan itu kepadanya, dan ia harus membayarnya menurut putusan hakim. 21:23 Tetapi jika perempuan itu mendapat kecelakaan yang membawa maut, maka engkau harus memberikan nyawa ganti nyawa, 21:24 mata ganti mata, gigi ganti gigi, tangan ganti tangan, kaki ganti kaki, 21:25 lecur ganti lecur, luka ganti luka, bengkak ganti bengkak.

New International Version:

21:22 "If people are fighting and hit a pregnant woman and she gives birth prematurely but there is no serious injury, the offender must be fined whatever the woman's husband demands and the court allows. 21:23 But if there is serious injury, you are to take life for life, 21:24 eye for an eye, tooth for tooth, hand for hand, foot for foot, 21:25 burn for burn, wound for wound, bruise for bruise.

New King James Version:

21:22 "If men fight, and hurt a woman with child, so that she gives birth prematurely, yet no harm follows, he shall surely be punished accordingly as the woman's husband imposes on him; and he shall pay as the judges determine. 21:23 But if any harm follows, then you shall give life for life, 21:24 eye for eye, tooth for tooth, hand for hand, foot for foot, 21:25 burn for burn, wound for wound, stripe for stripe.

Kata yang sangat penting untuk dianalisis dalam Keluaran 21:22-25 adalah kata (takhat) arti harafiahnya beneath and below. ${ }^{18}$ Menurut seorang ahli hukum Yahudi yang bernama Raphael Drai, mengatakan bahwa kata takhat yang terdapat dari ayat 23-25 jika diartikan dengan kata "ganti" maka itu adalah terjemahan yang kurang tepat, sebab kata takhat jika diterjemahkan harafiah maka itu memiliki arti "dibalik" atau "di bawah" oleh karenanya kurang tepat jika mengidentifikasikan kata tahta dengan arti (mata ganti mata, gigi ganti gigi, nyawa ganti nyawa) seperti yang terdapat dalam Alkitab dan kemudian disamakan dengan hukum yang berada di lokus Timur Dekat Kuno. ${ }^{19}$ Oleh karenanya, untuk mendukung pernyataannya, Drai, mengatakan bahwa kata takhat menjadi lebih tepat jika diterjemahkan dengan istilah "kompensasi". Karena menurut Drai istilah kata takhat yang diterjemahkan dengan kata "ganti" sesungguhnya melebihi makna yang sebenarnya, karena seluruh hukum Yahudi menolak kemungkinan implementasi literal dari rumusan talionik atau hukum pembalasan dendam yang disahkan oleh hukum.

Kata takhat memiliki arti harafiah beneath dan below, dari kata ini dapat diambil sebuah makna bahwa apabila seseorang melakukan tindakan yang melukai orang lain ${ }^{20}$, maka orang tersebut tidak mesti menggantinya dengan luka yang sama, tetapi ia bisa menggantinya dalam bentuk uang yang senilal dengan organ tubuh yang dilukai. Oleh karena nya J.A. Fitzmyer

${ }^{18}$ W. Justin Ilboudo,SJ,STL, "The Lex Talionis in The Hebrew Bible and the Jewish Tradition,"

Boston College, School of Theology and Ministry (n.d.).

${ }^{19}$ Ibid.

${ }^{20}$ Panjaitan and Lumingkewas, "KEADILAN DALAM HUKUM LEX TALIONIS: TAFSIR TERHADAP KELUARAN 21:22-25." 
memperluas pengertian kata takhat bukan dengan arti pembalasan dendam, melainkan dipakai untuk kata yang menunjuk penggantian kedudukan sesuatu milik terhadap orang lain. Contoh nya peristiwa pengorbanan Ishak yang dilakukan Abraham di gunung Moria (Kej.22). Ketika Allah melihat ketaatan dari Abraham maka Allah pun mengambil domba untuk dipersembahkan sebagai ganti dari (takhat) diri Ishak. ${ }^{21}$

Kata jika berarti kondisi kritis, sehingga sangat merugikan seorang wanita, dan akibatnya, jika janin meninggal, bagaimana Lex Talionis ini bekerja? Jika nyawa seumur hidup sebagai hukuman mati berlaku akibat kematian janin, bagaimana dengan Lex Talionis lainnya, misalnya mata ganti mata, gigi ganti gigi? Apakah bagian lain dari bagian tubuh ini hanya berfungsi untuk cedera wanita? Apakah gigi wanita patah? Bagaimana dengan luka bakar untuk luka bakar? Apakah dia terbakar? secara kiasan dapat mengungkapkan pentingnya pembayaran yang setara. Untuk mengerti lebih dalam mengenai teks Keluaran 21:22-35 maka sangat perlu untuk mengamati cedera tubuh yang juga terkait di dalam Keluaran 21:18-19 karena hukum cedera tubuh dalam ayat 18-19 tidak menerapkan hukum Lex Talionis tetapi cukup dengan pembayaran penuh biaya kerugian maka dianggap sudah cukup.

Dalam Keluaran 18-19 jika diamati cedera badan akibat perkelahian (yang mungkin sengaja) termasuk dalam kategori cedera badan, namun faktanya penerapan hukum Lex Talionis tidak ditemukan dalam kasus ini, dalam hal ini pemulihan korban adalah hal yang sangat penting. Untuk itu pertanyaannya jika dalam Keluaran 21:22-25 menerapkan Lex Talionis maka mengapa tidak juga diterapkan dalam Keluaran 21:18-19? Padahal terjadi kasus yang sama yaitu cedera tubuh oleh karenanya terkesan teks tidak konsisten. Oleh karenanya hukum Lex Talionis dalam Keluaran 21:22-25 tidak boleh dianggap sebagai sebuah hukum penerapan nya secara literal, namun harus dianggap sebagai sebuah kiasan. ${ }^{22}$ Sepanjang proses dalam Kel 21 : 22-25, keguguran diasumsikan dengan atau tanpa janin belum sepenuhnya hidup, jadi pembayaran finansial baik-baik saja. Jika ada kerusakan lebih lanjut pada seorang wanita, ini adalah kasus cedera tubuh seperti 21: 18-19. Lebih jauh, dengan cara penalaran ekonomi dan psikologis, pembayaran yang setara dari Lex Talionis menjadi kurang masuk akal; itu tidak membantu siapa pun, hanya menyisakan beban atau ketidaknyamanan seorang wanita, atau kebencian pelanggar. ${ }^{23}$ Arti kiasan dari lex talionis muncul dari gagasan bahwa hidup wanita itu berharga.

Secara teoretis, pembalasan adalah keadilan yang paling tepat dan paling ketat; tetapi dalam prakteknya kesulitan muncul. Bagaimana kekuatan pukulan diukur? Bagaimana luka bakar dan luka yang sama bisa ditimbulkan? Apakah mata harus diberikan ganti mata jika pelakunya adalah orang bermata satu? Dan, sekali lagi, apakah bijaksana bagi hukum untuk melipatgandakan jumlah warga yang dimutilasi dalam suatu komunitas? Pertimbangan semacam ini menyebabkan aturan tersebut dibuang begitu peradaban mencapai titik tertentu, dan umumnya cenderung pada penggantian kompensasi uang, untuk dibayarkan kepada pihak yang dirugikan oleh pelakunya. ${ }^{24}$ Meskipun tidak ada luka serius pada ibu atau anak itu, pengadilan diwajibkan untuk membebaskan orang yang bersalah atas tindakan agresifnya terhadap seseorang yang bukan merupakan teman nya dalam suatu pertarungan. Terlepas dari niat pria itu, apa yang dia lakukan bisa menyebabkan kematian anak atau ibu atau keduanya.

${ }^{21} \mathrm{Ibid}$.

${ }^{22}$ Yung Suk Kim, "Lex Talionis In Exod 21:22-25: Its Origin And Context," The National Library of Canada (2006).

${ }^{23} \mathrm{lbid}$.

${ }^{24}$ Charles Ellicott, Ellicot's Comentary For English Reader, 1979. 
Tapi jika ada luka serius, yaitu ibu atau anak itu cacat atau terbunuh, maka pengadilan akan mengikuti Lex Talionis (ayat 23-25) yang mengatakan, "Hukuman harus sesuai dengan kejahatan tersebut. ${ }^{25}$ Jadi dalam hal ini dinyatakan bahwa hukum tidak berlaku ketika tidak didapati luka atau cedera pada bayi atau ibunya sekalipun terdapat peluang untuk terluka dan hukum tidak perlu memberikan peringatan kepada orang tersebut. Tetapi hukum akan berlaku ketika seorang anak atau ibu itu mengalami cacat atau kecelakaan dan pelaku akan menerima balasan yang sesuai dengan yang telah dilakukan oleh orang tersebut sebagai ganti rugi. Dalam Keluaran 21:24 Mata untuk mata, gigi untuk gigi, tangan untuk tangan, kaki untuk kaki, Ini adalah daftar paling awal yang kita miliki dari Lex Talionis atau hukum sejenis untuk sejenisnya, yang kemudian terjadi di antara orang Yunani dan Romawi. Di antara yang terakhir, hal ini merupakan bagian dari dua belas meja, yang sangat terkenal di zaman purbakala, namun hukumannya kemudian diubah menjadi denda uang, untuk dipungut atas dasar kebijaksanaan. Tidak ada bagian dari jenis ini diserahkan kepada balas dendam pribadi; hakim memberikan hukuman bila terbukti bersalah tetapi jika tidak maka Lex Talionis akan benar-benar menghancurkan kedamaian masyarakat dan telah menabur benih kebencian, balas dendam, dan semua hal yang tidak biasa. ${ }^{26}$ Dalam hal ini Lex Talionis bukan untuk menjadikan hukum pembalasan dendam pribadi hanya saja setiap orang yang dikenakan kerugiannya boleh melakukan belas kasihan kepada setiap pelaku sehingga pelaku hanya perlu membayar ganti rugi dari pada yang telah dilakukannya.

Dengan demikian dapat dipahami bahwa hukum Lex Talionis memiliki pengertian yaitu, hukum tersebut merupakan hukuman yang dijalankan dengan cara memperlakukan pembayaran atau penggantian bagi kerusakan yang dilakukan oleh seseorang, dan biasanya hal ini disebut dengan kompensasi. Kompensasi merupakan bentuk Lex Talionis yang paling ringan, karena jenis hukuman lain tidak diberlakukan. Namun harus dipahami bahwa bentuk kompensasi ini diberikan tetap dalam jalur hukum yang dilakukan untuk menyatakan keadilan bagi setiap orang yang melakukan kesalahan. Melalui hukum lex talionis martabat dan harkat hidup manusia dihormati. Dengan demikian, secara prinsip Lex Talionis dipandang sebagai hukum yang menyatakan keadilan dalam kehidupan bermasyarakat, dan ini merupakan hukum yang sah bagi masyarakat yang harus diterapkan dalam segenap lapisan masyarakat yang ada.

\section{Implementasi Hukum Lex Talionis}

Hukum Lex Talionis yang diuraikan dalam Keluaran 21:22-25, bukanlah sebuah hukum kuno yang tidak memiliki implementasi bagi kehidupan masa kini. Jika prinsip hukum Lex Talionis tersebut ditarik dalam situasi masa kini, maka akan didapat beberapa bentuk kajian yang sangat relevan/implementatif bagi masa kini, yang sekiranya dapat menjawab setiap permasalahan berkenaan dengan keadilan dan kebenaran di masa kini. Karena harus diakui bahwa dunia sekarang sangat membutuhkan keadilan dan kebenaran yang hakiki, untuk itulah hadir hukum Lex Talionis yang direlevansikan dengan masa kini. Makna teologis mengenai keadilan Allah dalam karya-Nya yang berhubungan dengan manusia dapat dijumpai melalui pemeliharaan Allah yang tidak pernah berhenti.

Sifat Allah yang adil akan menjadi sebuah jaminan yang indah bagi setiap orang yang berada dalam posisi tertindas, dan melalui keadilan (dan juga kebenaran) Allah, maka setiap

${ }^{25}$ Warren W. Wiersbe, The Bible Exposition Comentary: Old Testament (Colorado: David C. Cook, 2004).

${ }^{26}$ Adam Clarke, Adam Clarke Commentary (New York City: Wesleyan Haritage Publications, 1996). 
orang berhak untuk menuntut keadilan bagi dirinya jika ia sedang berada dalam perkara. Perbuatan Allah senantiasa konsisten pada putusannya dan senantiasa dapat membedakan mana yang benar dan mana yang salah. Karena setiap perbuatan Allah bertujuan untuk menegakkan keadilan. Tindakan yang digunakan untuk menunjukkan pemeliharan Allah dalam keadilan adalah pembelaan Allah terhadap setiap perkara yang menimpa umatnya yang lemah, tertindas dan terpinggirkan. Allah akan menghukum setiap orang yang memerlakukan penindasan kepada orang yang lemah, dan semua ini Allah lakukan untuk memberikan keadilan bagi umat-Nya. Selain itu, tindakan Allah yang berupa penebusan juga merupakan tindakan keadilan Allah, melalui penebusan ini Allah membenarkan tindakan orang yang benar dan sebaliknya.

Hukum Lex Talionis yang dinyatakan dalam Keluaran 21:22-25 hendak menjabarkan tentang keadilan yang didasarkan atas keadilan Allah. Melalui hukum ini Allah hendak menegaskan bahwa setiap tindakan yang salah pasti akan menghasilkan sebuah hukuman dan hukuman tersebut dapat dilakukan secara langsung maupun melalui kompensasi. Jika pelaksanaan hukuman dilakukan secara langsung, maka hukuman yang diberikan harus seimbang dengan apa yang telah dihasilkan melalui tindakan sedangkan jika melalui kompensasi maka hukuman diberikan berdasarkan harga yang sesuai dengan apa yang dihasilkan dari setiap perbuatan pidana tersebut. Dengan demikian hukum Lex Talionis dalam Keluaran 21:2225 bukan menunjuk pada jenis hukum pembalasan (dendam), melainkan jenis hukum yang mengatur setiap tindakan hukum yang relevan dan seimbang. Inilah sebenarnya yang dimaksud dengan hukum Allah, yaitu sebuah hukum yang diberlakukan secara adil dan seimbang, sehingga tidak ada pihak yang diuntungkan atau dirugikan; semua dihargai sebagai manusia yang bermartabat dan setiap hak dibela. Hukum Allah yang adil ini menjadi sebuah patokan utama dalam menjalankan setiap bentuk pengadilan, sehingga keadilan bagi manusia dapat terwujud secara nyata.

Terdapat banyak pengertian dari tindakan keadilan Allah yang dinyatakan untuk mengukur setiap kesalahan atau tindakan seseorang dalam menerima hukuman atau sanksi yang berlaku. Lex Talionis adalah hukum keadilan yang tercipta dari hukum Allah dan diuraikan melalui hukum Musa. Musa memang memberikan hukum ini dalam upaya menjaga dan melindungi masyarakat. Dan untuk melakukan hukum Lex Talionis ini, setiap orang harus memasuki situasi pengadilan agar dapat menimbang dan mengukur kesalahan yang telah dilakukan, sehingga dengan keadilan yang tercipta sebagai suatu kebijakan dari keadilan yang dilaku-kan. Dalam hukum Allah berlaku prinsip bahwa Allah akan senantiasa membela mereka yang lemah dan tertindas; entah orang tersebut dalam posisi minoritas atau tidak. Allah tetap berpihak pada mereka. Oleh sebab itu hukum Lex Talionis memberi jaminan kepada setiap kelompok minoritas yang terpinggirkan ini untuk menuntut keadilan, agar melalui tindakan ini dapat diungkapkan siapa yang benar dan salah dengan tanpa adanya kompromi atau penilaian yang memihak siapapun. Hal ini sangat implementatif dalam kehidupan bergereja saat ini. Seringkali keberadaan gereja dewasa ini dipandang sebagai kelompok minoritas yang selalu mendapat perlakuan buruk dan diskriminatif.

Banyak kekerasan yang dialami gereja, yang menyebabkan gereja berada dalam posisi dilemahkan, dipinggirkan dan ditindas. Melalui hukum Lex Talionis gereja berhak menuntut keadilan yang seadil-adilnya, dengan cara mengajukan keberatan dan naik banding kepada pihak pengadilan dan memintakan keadilan bagi setiap kerusakan dan kerugian yang dialami oleh gereja. Jika gereja mengalami berbagai macam kerugian dari kelompok-kelompok radikal 
yang dengan sengaja melakukan tindak kekerasan terhadap gereja, maka melalui hukum Lex Talionis gereja berhak untuk mengajukan tuntutan kepada pengadilan agar seluruh kasus yang terjadi dapat dihadirkan dalam ruang pengadilan untuk menetapkan keadilan bagi gereja.

\section{KeSIMPULAN}

Berdasarkan pembahasan diatas maka penulis menyimpulkan bahwa hukum Lex Talionis bukanlah sebuah hukum yang didasarkan pada keinginan balas dendam, melainkan merupakan sebuah hukum yang didasarkan atas keadilan Allah yang hendak menjaga kelangsungan hidup dari umat manusia. Hukum ini menjadi sangat relevan dalam kehidupan berbangsa dan bernegara, khususnya di Indonesia yang terdapat banyak masalah ketidakadilan hukum. Melalui hukum ini setiap individu diakui martabatnya dan juga mendapatkan perlindungan yang maksimal terhadap hak asasi nya. Dan yang paling terutama dari semua ini adalah hukum Lex Talionis memungkinkan setiap orang yang mengalami ketidakadilan menuntut keadilan yang seutuhnya melalui lembaga pengadilan yang ada. Lex Talionis menjamin terjaganya setiap hak individu, sehingga melalui hukum ini keadilan benar-benar dapat ditegakan. Siapa yang benar akan mendapat kompensasi dan yang bersalah akan bertanggung jawab atas perbuatannya. Oleh karenanya tidak ada kompromi dan toleransi terhadap kesalahan apapun, maka dengan demikian keadilan bisa tercapai.

\section{REFERENSI}

Adam Clarke. Adam Clarke Commentary. New York City: Wesleyan Heritage Publications, 1996.

Bidari, Ashinta Sekar. "Ketidakadilan Hukum Bagi Kaum Sandal Jepit." Universitas Surakarta, n.d.

Charles Ellicott. Ellicot's Commentary For English Reader, 1979.

Christopher Wright. Hidup Sebagai Umat Allah-Etika Perjanjian Lama. Jakarta: BPK Gunung Mulia, 1995.

Gary Edward Schnittjer. The Torah Story. Malang: Penerbit Gandum Mas, 2015.

Hill, Andrew E., and John H. Walton. Survey Perjanjian Lama. Malang: Penerbit Gandum Mas, 2018.

Keil, C.F., and F. Delitzsch. Keil and Delitzsch Commentary On The Old Testament. Edinburgh: T.\&T. Clark, 1866.

Klein, William W. Introduction to Biblical Interpretation 2: Pengantar Tafsiran Alkitab. Malang, 2016.

Komnas HAM. "75 Tahun Indonesia Merdeka, Sebuah Harapan Bagi Penghormatan HAM Komnas HAM." Last modified 2020. Accessed May 30, 2021.

https://www.komnasham.go.id/index.php/news/2020/9/2/1545/75-tahun-indonesiamerdeka-sebuah-harapan-bagi-penghormatan-ham.html.

Lenta, Patrick. "The Lex Talionis, the Purgative Rationale, and the Death Penalty." Criminal Justice Ethics 34 (2015): 42-63.

Moriska Simamora. Lex Talionis (Menurut Keluaran 21:22-25). Yogyakarta: Diandra Kreatif (Kelompok Penerbit Diandra), 2018.

Panjaitan, Firman, and Marthin Lumingkewas. "KEADILAN DALAM HUKUM LEX TALIONIS: TAFSIR TERHADAP KELUARAN 21:22-25." Pengarah: Jurnal Teologi Kristen 1 (July 31, 2019): 73-84.

Purnamasari, Deti Mega. "Jaksa Agung Akui Penegakkan Hukum Di Indonesia Belum Penuhi Rasa Keadilan." Last modified 2020. Accessed June 2, 2021. https://nasional.kompas.com/read/2020/02/17/12002291/jaksa-agung-akui-penegakkanhukum-di-indonesia-belum-penuhi-rasa-keadilan.

Robert M. Peterson. Tafsiran Alkitab: Kitab Keluaran. Jakarta: BPK Gunung Mulia, 2006. 
Roy Zuck. Biblical Theology of The Old Testament. Malang: Penerbit Gandum Mas, 2005. Th. C. Vriezen. Agama Israel Kuno. Jakarta: BPK Gunung Mulia, 2015.

VanDrunen, David. "Natural Law, the Lex Talionis, and the Power of the Sword." Liberty University Law Review 2, no. 3 (March 2008).

W. Justin Ilboudo,SJ,STL. "The Lex Talionis in The Hebrew Bible and the Jewish Tradition." Boston College, School of Theology and Ministry (n.d.).

Warren W. Wiersbe. The Bible Exposition Commentary: Old Testament. Colorado: David C. Cook, 2004.

Yung Suk Kim. "Lex Talionis In Exod 21:22-25: Its Origin And Context." The National Library of Canada (2006). 